"No." If such instances occur they are the exception, not the rule, and are then due to a peculiar psychoIogie state of the individual. Consumptives as a class are grateful to their friends, physicians and nurses and devoted to their families. At the beginning of the disease, it is true, a decided irritability may often be noticed, with a dislike or indifference to pleasure or work; but beyond this no distinct psychologic changes can be observed. Many consumptives are very sanguine about the outcome of their disease, others are depressed, some totally indifferent. Even in the case of a fatal termination most of them retain a clear intellect until the last. The character and disposition of the consumptive varies as it does in well people; but to say that by reason of his disease he is easily turned against his friends by designing people would be absurd and do him the greatest injustice.

There is enough phthisiophobia in the world already, and let us not give the phthisiophobic another cause to increase his fear of or dislike for the unfortunate consumptive. Thousands of these are as noble, true and generous as any other class of invalids or well people.

Consumption is a preventable, curable, communicable, but by no means a dangerously contagious disease. Among those who were once afflicted with it and were ultimately lastingly cured we count the brightest minds, the most generous and truest hearts. The German poet Goethe, our own Peter Cooper, the French poet Coppee, were among them. The greatest German specialist Herman Brehmer, who cured himself, and thousands of others from this disease; his two greatest contemporaries and co-workers, still alive and active. Dett. weiler in Germany and Trudeau in this country, all are ex. amples of the highest type of men. The story of the lives and work of those who have passed on and those still with us give evidence of their great qualities of heart and mind, their truth and devotion to friends, family and mankind in general.

16 West Ninety-fifth Street. S. A. KNOPF, M.D.

\section{Suggestive Therapeutics vs. Hypnotism.} Chicago, Sept. 26, 1903.

To the Editor:-In THE JourNaL, Sept. 26, 1903, appears an editorial under the above heading, which challenges some comment. - . Hypnotism, as now understood by men who have had personal experience with it, is really synonymous with suggestion. The Charcot school is responsible for the term artificial hysterical state occasionally cropping up in medical literature. Charcot conducted his experiments with hypnotism on about a dozen or more hysterical patients which were demonstrated to the whole world in order to prove his theories. The peculiar method used and the frequency with which these patients were hypnotized contributed toward their becoming perfect automatons of unconscious suggestion. Hypnotism as practiced now is nothing else but suggestion administered during a state of greatest susceptibility to suggestion. I can not conceive how you can recommend suggestive therapeutics and condemn hypnosis when to successfully practice the first the second is often an absolute necessity. Not all people are alike suggestible and particularly are hysterical patients refractory to suggestions from without, for they are mostly dominated by autosuggestions. If suggestion is to be of value it must be administered during the time of greatest susceptibility. Many people are susceptible to suggestion in the waking state and these are the proper subjects for indirect waking suggestions by means of innocuous drugs, electricity, etc. In some cases we are forced to place such patients into the condition of greatest receptivity for our suggestions, I mean into hypnotism. The so-called dangers from hypnotism are imaginary, and although $I$ have hypnotized hundreds of times $I$ have never seen any ill effects from its use. Bernheim, Liebault, Ford, Wetterstrand and a host of others who practiced hypnotism thousands of times have had similar experiences. Because of the Mendel commission having assumed an unfavorable attitude toward hypnotism is no valid argument against its use by the physician in properly-selected cases.

Julius Grinker, M.D.
Physiology in the University College of Medicine.

Chicago, Sept. 28, 1903.

To the Editor:-My attention has been called to the fact that in my report on Curriculum in the National Confederation of State Medical Examining and Licensing Boards (THE Journal, Aug. 15, 1903, pp. 456-461), the University College of Medicine, Richmond, Va., is not credited with any work in physiology. This college devotes to this study 53 hours of lectures and 27 hours of recitations. I am informed by the proctor that the number of hours has been increased for the coming session. Any other errors noted in the above report will be corrected most cheerfully if sent to the undersigned.

70 State Street.

George W. Webster, M.D.

\section{The Visiting Physician in Berlin. BY DENSLOW LEWIS, M.D. CHICAGO.}

(Concluded from page 798.)

With a slight knowledge of social usage and with the ability to speak the language to a reasonable extent, the American visitor's sojourn in the German metropolis will be most enjoyable and profitable. The wealth of clinical material is unsurpassed elsewhere, and the sensible manner in which it is utilized will be appreciated. The friendly reception extended to Americans and the invariable courtesy that prevails on all sides combine to make the visitor welcome and to facilitate his studies. The months of April and August are vacation months when many medical men leave town. The months of March and October are also vacation months, but especially valuable to the medical visitor for the vacation courses (Ferienkursen) are given at this time. These courses are unusually interesting, for it is here that the younger teachers have a chance to exploit themselves and the older men to bring for. ward prominently special points in diagnosis and treatment. The cost is insignificant. For ten dollars a month you can see Lexer and others connected with Bergmann's Klinik perform major operations every morning, and you can do minor operations yourself in the Poliklinik, where over 20,000 patients are treated every year.

If one's stay is to be protracted it is well to matriculate and be enrolled as a student. It is imperative to show a passport, and it is customary to present the diploma. I had forgotten to bring either, but I procured the passport from our Embassy for about ten marks and I showed the dean a copy of my "Obstetric Clinic" I had with me to give to Olshausen. In arranging to matriculate consult the man in charge, called the "Pfoertner," or better still, his wife, who is an English woman. They keep the buffet in the university building and supply the student with information as well as sandwiches and drinks. They told me the day and hour I was expected to appear in person and qualify.

When the appointed time arrived I found myself, together with some fifty others, seated in the "Aula," as the assembly hall of the university is called. At one end of this hall is a throne or pulpit arrangement with leather chairs in front and seats along each side of the room. I learned afterward that this is where the candidate for graduation takes leave of the university by publicly defending three theses before all the world-a function known as "promovieren." At the other end of the room is a large table at which are seated several dignified gentlemen who superintend the matriculation. When my name was called I approached the table and was interviewed by the gentleman at the end. He looked at my passport and compared the name with the name in my book on obstetrics. Being satisfied apparently with my credentials, I was directed to the rector, who wrote my name and his own on a large Latin document, which I deciphered later and learned that it was my certificate of matriculation. I then passed along to another gentleman, who had me write my name and address in a large book. The next gentleman had me write my name on a numbered student's card, which $I$ was instructed always to have on my person and which, I learned afterward, exempted me from arrest or interference by the police. The next 